\title{
INDENIZAÇÃO DE FAMILIARES DE DETENTOS
}

\section{Maria Eduarda Dias da Costa}

Acadêmica de Direito da Universidade Federal do Amazonas.

E-mail: dudadiiass@outlook.com

\section{RESUMO}

Visando compreender os códigos penais em relação aos detentos, este estudo objetiva esclarecer os motivos para o ressarcimento dos presidiários. Propõe-se a cognição das razões para a indenização visto que, as garantias fundamentais impostas pela Constituição Federal são direcionadas a todas as pessoas. Utilizouse como metodologia o método dialético comparado e dialógico, no primeiro revelou-se a perspectiva de autores para elucidar a pesquisa. Conferindo as perspectivas, surgem divergências e similaridades, definindo assim uma conclusão. 0 segundo caracteriza-se em diálogos com outras áreas do conhecimento como história e sociologia. A abordagem inicia-se com a péssima realidade prisional e a falta de um código penal mais apurado e especifico. Verificou-se como resultado que as indenizações ocorrem devido à omissão ou irresponsabilidade do Estado perante os danos causados aos envolvidos no sistema carcerário. Ademais, a população civil demonstra repúdio a situações satisfatórias ao detento, por isso o encarcerado é excluído erroneamente da sociedade.

PALAVRAS-CHAVE: Detentos. Indenização. Sistema Penitenciário. Nexo Causal. Estado. 


\section{INTRODUÇÃO}

O Sistema Penitenciário tem por finalidade o cumprimento da pena, com o objetivo da ressocialização dos indivíduos. Ao redor do globo, cooperam diversas formas de configuração desse sistema. Os Estados Unidos é o país com o maior número de encarcerados, conhecido como o país da lei e da ordem ("law and order"), nele vigoram regras criminais duras e forte policiamento. Apesar do histórico de políticas penais duras, dados dos últimos anos mostram tendência de redução do número de presos nos Estados Unidos. A segunda maior população carcerária é a da China, sendo considerado um dos sistemas mais brutos do mundo, recebia inúmeras críticas de órgãos governamentais, porque até 2013 existiam detentos que eram enviados a campos de trabalho forçado. Com a reforma prisional deu-se por fim essas práticas de tortura. A Rússia possui a terceira maior população carcerária do mundo e uma das mais altas taxas de encarceramento. Os relatos sobre o sistema penitenciário do país não costumam ser agradáveis. Abusos, arbitrariedades, violações de direitos humanos e falta de transparência no cuidado com presos são frequentes.

Diferentemente dos EUA, China e Rússia, a Noruega e a Holanda são os países com os menores índices de cárcere, prevalecem políticas mais liberais em relação ao sistema penal. As cadeias holandesas e norueguesas são grandemente distintas ao do Brasil: contam com amplas áreas verdes, bibliotecas, mesas de piquenique e redes de vôlei. Os detentos são autorizados a circular livremente por esses espaços e podem até usar facas para cozinhar. Adota-se, novamente, a ideia de que a rotina na cadeia não deve ser muito diferente da rotina fora dela. Essa abordagem ajudaria o preso a retomar a vida mais facilmente ao sair da prisão. Por fim, a recuperação do preso é personalizada e procura abordar as causas que levaram a pessoa a cometer o crime. Assim como na Noruega, as sentenças também são curtas: a maioria dos condenados na Holanda cumprem penas de um ano ou menos. ${ }^{47}$

O Brasil encontra-se com a quarta maior população carcerária do mundo, dados do Levantamento Nacional de Informações Penitenciárias (Infopen), revelam que o número de presos no Brasil aumentou 168\% de 2000 a 2014.

O Sistema Carcerário brasileiro encontra-se em crise desde o início do século. Esta situação é perceptível na precariedade dos centros prisionais ou até na falta destes para alocar os presos. Houve acontecimentos no Brasil que comprova a alarmante realidade carcerária,

\footnotetext{
${ }^{47}$ Segundos dados demográficos do site BBC.
} 
entre eles a chacina de Carandiru e as guerras de facções em Roraima e no Amazonas, estes últimos ocasionaram uma baixa de 89 detentos. $^{48}$

O Supremo Tribunal Federal (STF) determinou no dia 16/02/2017 que os presos possuem direito de ressarcimento pecuniário devido às condições precárias dos presídios. Afirmando que estariam sendo violados os princípios determinados na Constituição a qualquer homem. Os ministros Luís Roberto Barroso, Edson Fachin, Rosa Weber, Luiz Fux, Dias Toffoli, Gilmar Mendes, Celso de Mello e a presidente do STF, Cármen Lúcia, votaram a favor do pagamento da indenização.

A população em geral assume a decisão como injusta porque encara o apenado como um ser sem qualquer meio de reabilitação ou um homem sem garantia de direitos. A fim de elucidar o pretexto da indenização torna-se necessário abordar: a evolução das leis penais e a caracterização do termo dano moral.

Faz-se necessária a reflexão: Quais os motivos para o recebimento de indenização por parte dos familiares?

O primeiro ponto debatido neste artigo será a denominação de danos, o artigo 159 da Constituição Federal determina a indenização por dano causado seja de qualquer espécie. Relaciona-se assim danos morais com a ofensa ou violações de bens da ordem moral de uma pessoa, entre eles a honra, a integridade, a privacidade, a imagem ou a intimidade.

O Estado atua como pessoa jurídica do Direito Público ${ }^{49}$, e seu dever de indenizar têm previsão constitucional no artigo $37, \S 6^{\circ}$ da Constituição Federal, desse modo a responsabilidade dos danos causados aos detentos recai sobre a administração pública.

Este estudo não visa diminuir a culpabilidade do apenado ou defender a ideia de impunidade, ele defende o cumprimento das normas e princípios contidos em nossa Constituição Federal de 1988.

Claramente não há dinheiro nos cofres públicos suficiente para pagar todos os processos abertos contra o Estado. A responsabilidade do Estado é dada somente quando se prova um nexo causal, isto é, comprovar a relação de dano causada entre o apenado e o órgão de administração, há duas vertentes em como se provar o nexo, outra grande questão debatida neste trabalho.

O Estado ainda pode realizar um processo subjetivo, quando há comprovação de culpabilidade do agente penitenciário, então este deve remunerar o órgão por sua negligencia

\footnotetext{
${ }^{48}$ Segundo dados da Secretaria de Segurança Pública do Amazonas houve baixa de 56 detentos na capital e a Secretaria de Justiça e Cidadania foram 33 detentos morto, somando-se 89.

${ }^{49}$ Segundo a professora Maíra Zapater, o Estado seria exatamente a pessoa jurídica do Direito Público.
} 
no trabalho. Resume então que o Estado indeniza a vítima, o agente indeniza o Estado, regressivamente.

Ainda restam dúvidas quanto ao tipo de ressarcimento ao dano moral, a ministra Cármen Lúcia afirma que ela é pecuniária enquanto Barroso acredita na diminuição de três dias da pena a cada sete dias em condições precárias. A partir disso não se sabe o quantum indenizatório a ser pago, normalmente segue a idéia de proporção ao dano causado, mas é árduo delimitar os danos morais causados.

A relevância social desta pesquisa é levar cognição aos cidadãos que desconhecem da Constituição e revelar a sua gama de direitos e deveres, tanto para o homem com e sem liberdade. Ademais, o presente estudo visa diminuir as injustiças que ocorrem no Brasil, efetivando dessa forma os direitos impostos pela Constituição Federal.

A importância específica deste trabalho no avanço de conhecimento seria a percepção da ausência de um Código Penal referente aos detentos, dessa forma aprimora-se esta área do Direito Penal. Além disso, a experiência de centros penitenciários em precárias condições e com incidência de doenças, motiva a busca por inovações que tentem desafogar os presídios ou até melhorar o processo ressocializador visando à diminuição de criminosos reincidentes.

\section{DANO MORAL: IDENTIFICAÇÃO E CONCEITUAÇÃO}

Dano Moral é quando uma pessoa se acha afetada em seu ânimo psíquico, moral e intelectual, seja por ofensa a sua honra, na sua privacidade, intimidade, imagem, nome ou em seu próprio corpo físico, e poderá estender-se ao dano patrimonial se a ofensa de alguma forma impedir ou dificultar atividade profissional da vítima. ${ }^{50}$ Exemplos: Um cliente que tem seu nome inserido em cadastro de inadimplentes, mesmo que tenha pago o débito. Posteriormente, sofre a consequência de ter negado o acesso ao crédito em estabelecimentos comerciais e bancários ou caso de atraso de vôo por culpa exclusiva da companhia aérea por prática de overbooking (excesso de vendagem de bilhetes sobre as poltronas disponíveis).

\footnotetext{
${ }^{50}$ Segundo o renomado jurista Caio Mário da Silva Pereira, o jurista acredita que a indenização objetiva reparar ou reestabelecer o equilíbrio.
} 
O dano moral corresponderia às lesões sofridas pela pessoa humana, consistindo em violações de natureza não econômica. É quando um bem de ordem moral, como a honra, é maculado. A pessoa lesada tem direito à reparação do dano, seja porque sofreu constrangimentos, ou porque sofreu perda objetiva.

O Estado como órgão regulador e mantenedor do sistema prisional deveria garantir aos detentos a preservação da imagem e honra, respeito à integridade física e moral, e certos fundamentos como "o preso conserva todos os direitos não atingidos pela perda da liberdade". A realidade brasileira mostra que há muitos casos que isso não é assegurado e a partir dessas negligencias é passível a abertura de um processo indenizatório. Qualquer individuo que esteja sob o arbítrio do Estado devem ser protegidos e seus direitos garantidos pelo órgão.

Dano Moral é um termo que tange a interpretação sistemática do artigo 186 do Código Civil que, alude a "violação" de um direito não apenas como reparação por danos materiais. A fundamentação do ressarcimento às lesões subjetivas surge de dois incisos do Código Civil Brasileiro: “Art. 186. Aquele que, por ação ou omissão voluntária, negligência ou imprudência, violar direito e causar dano a outrem, ainda que exclusivamente moral, comete ato ilícito" e "Art. 927. Aquele que, por ato ilícito (arts. 186 e 187), causar dano a outrem, fica obrigado a repará-lo. "

O primeiro ao afirmar "exclusivamente moral" já prenunciava o dano moral como ato ilícito e o segundo complementa o estudo alegando a possibilidade de ressarcimento ao lesado. No entanto, seu significado é vasto, exige preparo e acuidade para melhor definição, a partir dessas divergências que se supõem as inúmeras hipóteses de ressarcimento

Savatier (1989) afirma que dano moral seria qualquer sofrimento que não fosse causa de uma perda pecuniária e abrange atentado a reputação, a autoridade legítima, ao pudor, a segurança e a tranqüilidade da vítima. O professor Yussef Said Cahali (1998), em seu livro define como a privação ou a mitigação de bens de valores precípuos na vida do homem. Yussef e Savatier então compartilham da mesma linha conceitual, a qual o dano moral seria agravo a bem imaterial, causando reflexo subjetivo na vítima. Exemplos de direitos morais é a integridade física, a saúde, a correção estética, a liberdade e a reputação.

Considera-se assim dano moral todo aquele dano com prejuízos que não atingem em si o patrimônio, são ofensas a bens imateriais, desprovidos de valor substancial e insusceptíveis a avaliação em dinheiro.

Quanto a sua identificação, surgem duas correntes para elucidar essa questão, a primeira requer a comprovação da lesão sofrida, porque assim haverá um parâmetro para 
definir a indenização, se julgado como condenado. A segunda defende que a vítima ateste a violação de um direito constitucional.

O Supremo Tribunal de Justiça segue a segunda corrente, decidiu-se não ter relevância a prova do dano e sim o simples fato de violação de direitos. Chama-se isso de nexo causal, a relação entre o agente causador e o dano à vítima, ao se comprovar tal nexo a indenização é deferida, no entanto, nova questão surge, o valor fixado para o quantum indenizatório.

O início da reparação por dano moral se conjecturou com o Código Hamurabi (1772 A.C), que julgava o desrespeito de um homem contra outra mulher como um ato que merecia metade de sua cabeça raspada. As leis de Manu, de origem hindu, a pena a um acusado era por valor pecuniário. Dessa forma, tem se a ideia de reparação indenizatória por casos de dano moral e material.

Os danos causados aos detentos são de responsabilidade do Estado, então esse valor deve ser pago e definido pelo órgão administrativo. Com as condições presente nas unidades presidiárias, é evidente que os direitos humanos daqueles são mitigados. Antonio Molina (2008) apresenta uma crítica ao Estado quanto a essa realidade, em suas palavras:

"Pedir uma modificação qualitativa da pessoa do delinquente, é sem dúvida, pedir demasiado. Não parece fácil que o estado garanta a ressocialização do condenado, quando não é capaz sequer de assegurar sua vida, sua integridade, sua saúde". (MOLINA, 2008, p.156).

O fato de o apenado estar sem liberdade, não fortalece a ideia que seus outros direitos deixem de ser assegurados. Integridade física e garantia mínima de saúde são os direitos fundamentais mais mitigados. O site Justificando publicou um artigo tratando dos motivos de haver pagamento para os detentos. O autor prenuncia afirmando que esse tema sempre carrega alta reações morais, e ele cita diversos casos em que cabe ao Estado a indenização, como as famílias de policiais mortos em serviço, famílias de pessoas que morram em hospitais públicos por negligência ou imprudência do Estado, aliás, há casos emblemáticos de condenação do Brasil na ONU e na Corte Interamericana de Direitos Humanos por mortes no sistema público de saúde. E, pelos mesmos fundamentos, pessoas presas (ou seus familiares, nos casos fatais) têm direito a serem indenizadas por danos causados enquanto estavam sob a custódia compulsória do Estado.

Então se compreende que o Estado é obrigado a indenizar danos causados a pessoas que estavam de alguma forma, sob sua responsabilidade direta ou o seu serviço. Não se coloca em pauta a diminuição da ação do presidiário ou de sua pena o que esse estudo visa é 
determinar as inúmeras infrações cometidas contra o detento que são indenizatórias. Como o Estado é a pessoa jurídica do Direito Público a ele cabe o ressarcimento.

Cabe ratificar que não há dúvidas ao que tange à reparabilidade de qualquer tipo de dano, seja de natureza patrimonial ou moral, o Código Civil brasileiro reconhece ambas as situações.

A questão crucial relativa ao dano moral é seu quantum indenizatório, torna-se mais difícil determiná-lo quando o indenizado é um homem que, para a sociedade, não mereceria tal direito, um detento.

\subsection{DETERMINAÇÃO DO QUANTUM INDENIZATÓRIO}

O grande debate relacionado ao dano moral não é necessariamente sua conceituação, a questão está na fixação de um valor para suprir a falta de um bem que não seja material. Essa discussão é tão recorrente que o Supremo Tribunal Federal (STF) obteve diferentes posições entre os ministros quanto à reparação a ser adotada, ficando majoritária a indenização em dinheiro e parcela única. Cinco votos - ministros Teori Zavascki, Rosa Weber, Gilmar Mendes, Dias Toffoli e a presidente do STF, ministra Cármen Lúcia mantiveram a indenização estipulada em instâncias anteriores, de R \$ 2 mil. Já os ministros Edson Fachin e Marco Aurélio adotaram a linha proposta pela Defensoria Pública de Mato Grosso do Sul, com indenização de um salário mínimo por mês de detenção em situação degradante.

A proposta feita pelo ministro Luís Roberto Barroso, em voto proferido em maio de 2015, substituía a indenização em dinheiro pela remição da pena, com redução dos dias de prisão proporcionalmente ao tempo em situação degradante. A fórmula proposta por Barroso foi de um dia de redução da pena (remição) por 3 a 7 dias de prisão em situação degradante. Esse entendimento foi seguido pelos ministros Luiz Fux e Celso de Mello.

Em síntese, o STF deu um passo largo e fundamental ao não aceitar mais um sistema atentatório à dignidade da pessoa humana. Essa decisão do STF, certamente, levará como já fizeram países do Primeiro Mundo para resolver a lotação exagerada nos seus cárceres, a uma ampla e profunda reforma no sistema de penas em regime fechado.

A dificuldade em definir a quantia deu-se pelo retardamento de aceitar dano moral como um bem ressarcível. A indenização busca aliviar a dor ou mágoa da vítima e determinar 
uma "pena" ao infrator. Pablo de Paula (2017) escreveu um artigo que sumariza a grande questão em torno dessa temática.

\begin{abstract}
A principal dificuldade subsistente acerca dos danos morais na atualidade não está pautada em sua conceituação, nem mesmo na possibilidade de reparação. O grande dilema existente em torno do assunto é fixação do quantum indenizatório. Este é o tema principal do presente trabalho, e será destrinchado no capítulo seguinte.
\end{abstract}

Sobre as diferentes concepções debatidas no STF, sobre a reparação do dano moral, Belmonte (2014) elenca quatro correntes no direito, a negativista, positivista, limitativa e afirmativa.

Para os negativistas a atribuição de valor pecuniário à dor, honra ou outro direito de personalidade seria imoral, visto que os mesmos não possuem valor pecuniário. Ademais, impossível seria mensurar o dano alegado, sendo a reparação mero arbítrio do juiz. E complementa Belmonte:

Para os negativistas, tendo a prestação contida na obrigação conteúdo econômico e não sendo o componente puramente moral estimável em dinheiro, não se pode cogitar de reparação pela simples inexistência de obrigação jurídica.

Objetou-se no sentido de que a patrimonialidade da prestação não se confunde com o interesse do credor, que pode ser econômico ou moral, não constituindo reparação de danos morais uma fixação de preço para a dor e sim uma compensação do lesado (BELMONTE, 2014, p 66).

Belmonte (2014) complementa que para os positivistas, alguns impõem limitações para a reparação do dano moral e outros nem restrições fazem.

$\mathrm{Na}$ corrente limitativa se encontram dois grandes juristas brasileiros: Orlando Gomes e Agostinho Alvim, os quais compreendem que "a compensação ocorre somente quando o dano repercute no patrimônio do lesado ou quando o legislador expressamente e somente nas hipóteses previstas, fixa uma indenização" (BELMONTE, 2014, p. 66).

Por ultimo, temos a corrente afirmativa, que segundo Belmonte (2014) a qual entende que a fixação do valor compensatório independe de haver uma repercussão no patrimônio do lesado. Nos dizeres de BITTAR (1980), ao menos propiciam a ele "lenitivos, confortos, prazeres, e outras sensações, ou sentimentos aliviadores, que através da moeda, se podem obter, como os experimentados em viagens, terapia, leitura, e outras tantas (BELMONTE, 2014, p. 66)".

A função da quantia paga em dinheiro, em espécie, não é a de repor um desfalque patrimonial, mas apenas a de representar para a vítima uma satisfação igualmente moral ou, 
que seja psicologicamente capaz de neutralizar ou anestesiar em parte o sofrimento impingido.

Em bem elaborado artigo, as professoras Zely Fernanda de Toledo Pennache Machado (2007) e Renata de Carvalho Morishita (2007) discorreram que "a indenização não tem o condão de retornar as coisas ao "status quo ante" já que isso é inviável em se tratando de danos morais". Citada no mesmo artigo, a eminente jurista Teresa Ancona Lopes de Magalhães (1980) preconizou que "A ofensa derivada de lesa-o a um direito da personalidade não pode ficar impune e, dentro do campo da responsabilidade civil, a sua reparação tem que ser a mais integral possível para que, caso não possam as coisas voltar ao estado em que se encontravam antes, tenha a vítima do dano, pelo menos alguma satisfação ou compensação e, dessa forma, possa ver minorado o seu padecimento".

A reparação pelo dano moral tem logrado várias explicações, não visa, de modo algum, a de acabar através do dinheiro o sofrimento de ninguém, até porque esta é insuscetível de mensuração, é irreparável. Além do mais, a justificação da reparação do dano moral tem sido o de possibilitar ao lesado, formas para ajudar a mitigar-lhe a dor. Sobre isso se diz: "Para uma pessoa que perdeu o filho em condições trágicas, é óbvio que a reparação do dano moral visa a permitir o desfrute por essa pessoa, às vezes se submetendo a tratamento psicológico, cujo objetivo é melhor aceitar a perda.” (FERNANDES, 2017).

Muitas decisões têm utilizado como paradigma para a fixação dos danos morais o Código Brasileiro de Telecomunicações e a Lei de Imprensa que possuem limitações para a definição do quantum.

Busca-se uma indenização justa e próxima da realidade dos fatos, para que esta possa elevar a valoração humana por meio do resgate da dignidade. Na situação do dano material, calcula-se exatamente a perda sofrida do patrimônio da vítima e a indenização será esse exato montante. Mas no dano moral, a apuração do quantum indenizatório é complexa, não se mede pecuniariamente, ou seja, não há dimensão substancial ou material.

Aconselha-se então para a delimitação deste montante que o juiz coloque em pauta, as condições econômicas do lesado e do causador do dano, o grau de culpa deste e a reincidência do elemento volitivo. Desta forma atingirá o quantum indenizatório, sem que haja injustiça para ambos ou que está ação sirva de enriquecimento para o ofendido. Ao final da decisão o órgão de justiça deve aplicar a teoria do desestímulo, evitando a reincidência de delitos. 


\subsection{DIREITOS, GARANTIAS E DEVERES DOS DETENTOS}

Dura Lex, Sed Lex é uma expressão em latim cujo significado é "a lei é dura porem é a lei”, deve-se respeitar a lei, ainda que muitos não concordem com ela. O sistema brasileiro, a civil law, determina que a fonte do direito são as leis e enquanto não mudarem e não criarem uma nova Constituição, devemos segui-la. Desse modo os presidiários possuem garantias tanto quanto outro homem, assegurados pela Carta Magna.

A garantia de direitos aos detentos possui uma história longa. Podemos citar um dos principais códigos que deram base ao Código de Hamurabi (1772 A.C), a Lei de Talião, na qual a vingança é realizada pela vítima e ocasionando a mesma proporção de dano do infrator.

Ao fim do século XVIII, com a chegada do iluminismo, houve crescimento de ideais humanistas. Em 1789, a Revolução Francesa culminou com a Declaração dos Direitos do Homem e do Cidadão, documento que determinou a punição dos homens unicamente pela Lei, não cabendo ao homem como indivíduo tal decisão. Seguindo a linha do iluminismo, ao fim da Segunda Guerra Mundial e o espantoso número de mortes (torno de 50 milhões), aturdiu a Organização das Nações Unidas (ONU), que consequentemente proclamou a Declaração Universal dos Direitos Humanos, neste documento encontram-se "ninguém será submetido à tortura, nem a tratamento ou castigo cruel, desumano ou degradante" (art. V); "todo homem tem o direito de ser, em todos os lugares, reconhecido como pessoa perante a lei” (art. VI); "todos são iguais perante a lei e tem direito, sem qualquer distinção, a igual proteção da lei” (art. VII); Por fim no ano de 1955, a ONU, visando a ressocialização correta do apenado, adotou, sob forma de Resolução, as "Regras Mínimas para o Tratamento dos Reclusos".

O capitulo IV (arts. 38 usque 60) do Estatuto Executório-Penal aborda, especificamente, dos deveres, dos direitos e da disciplina. Em suma tal capítulo determina o modo que o detento deve portar em relação a outros detentos, agentes penitenciários e todos aqueles envolvidos em seu dia-a-dia, além da obediência ao Estado e seus funcionários e por último a higiene pessoal e da cela. Licínio Barbosa (2011) aborda efusivamente os deveres, garantias e direitos. Ele prenuncia:

Os deveres do presidiário estão elencados (arts. 38 usque 39), tais como:

\footnotetext{
a) comportamento disciplinado;

b) fiel cumprimento da sentença;

c) obediência ao servidor;

d) respeito às pessoas com quem deva relacionar-se, no dia-a-dia da prisão;

e) tratamento urbano e respeito no trato com outros condenados;

f) não fugir nem tentar fuga, individual ou coletivamente;

g) não subverter a ordem nem a disciplina vigentes na prisão;
} 
h) execução do trabalho, das tarefas e das ordens recebidas de quem de direito;

i) submissão à sanção disciplinar imposta;

j) indenização à vítima, ou a seus sucessores;

1) pagamento ao Estado das despesas decorrentes de sua manutenção;

m) higiene pessoal;

n) asseio da cela, quarto ou alojamento;

o) preservação dos objetos de uso pessoal.

A enunciação desses deveres não é exaustiva, eis que outras "obrigações legais inerentes", ao estado de presidiário podem ser exigidas pela autoridade penitenciária, ou pelo juiz das execuções penais.

As garantias constam na Constituição de 5 de outubro de 1988 , centram-se no art. $5^{\circ}$ e vários de seus incisos:

a) no inciso I, o princípio da isonomia entre homens e mulheres;

b) no inciso II, o princípio de legalidade;

c) no inciso III, a terminante proibição da tortura e dos maus-tratos (tratamento desumano ou degradante);

d) no inciso VII, a garantia da assistência religiosa;

e) no inciso $X$, a preservação da intimidade, da vida privada, da honra e da imagem, assegurada indenização, nos casos de violação;

f) no inciso XLII, a garantia de que não será discriminado por preconceito racial;

g) no inciso XLV, a garantia de que a pena não passará da pessoa do condenado;

h) no inciso XLVI, a certeza de que a lei regulará a individualização da pena;

i) no inciso XLVIII, a garantia de que "a pena será cumprida em estabelecimentos distintos, de acordo com a natureza do delito a idade e o sexo do apenado";

j) no inciso XLIX, a garantia do "respeito à integridade física e moral";

Os direitos do preso estão nitidamente elencados tanto no Código Penal como na Lei de Execução Penal, aliás, ambos da mesma data, — 11 de julho de 1984. No Código Penal (Lei 7.209/84), podemos rastrear esses direitos em várias passagens desse estatuto, quais sejam:

a) o direito à individualização da pena, através do exame de classificação para cumprimento da pena privativa da liberdade, no regime fechado (art. 33, c/c o art. $34)$;

b) o direito ao regime semi-aberto, se a pena de prisão é superior a quatro anos e não excede a oito anos (art. $33, \S 2^{\circ}$, letra b);

c) o direito ao regime aberto, se a pena de prisão for "igual ou inferior a quatro anos" (art. 33, $\S 2^{\circ}$, letra c);

d) no art. 37, a previsão de que "as mulheres cumprem pena em estabelecimento próprio";

e) no art. 38, a previsão de que "o preso conserva todos os direitos não atingidos pela perda da liberdade";

Já na Lei de Execução Penal, a matéria se acha disciplinada nos arts. 40 usque 43, com a seguinte enunciação:

a) direito à integridade física e moral do preso provisório, ou presidiário;

b) direito à alimentação;

c) direito ao vestuário;

d) direito à remuneração pelo trabalho; 
e) direito à previdência social;

f) direito à instituição de um pecúlio;

g) direito ao descanso e à recreação, equilibradamente ao trabalho;

Nele também estão previstos os direitos que regulamente são minimizados, aqueles que são os mais violados são: no art. 38, a previsão de que "o preso conserva todos os direitos não atingidos pela perda da liberdade"; "direito à integridade física e moral do preso provisório, ou presidiário"; "direito à assistência material, à saúde, à assistência jurídica, educacional, social e religiosa; "direito a igualdade de tratamento, salvo quanto às exigências de individualização da pena".

Conclui-se assim que as garantias impostas pela Constituição Federal brasileira são direcionadas a todas as pessoas, isto é, não serão suprimidos os direitos dos indivíduos que cumprem pena privativa de liberdade. Para elucidar tal fato, Ives Granda (2005) anuncia:

O encarcerado pelo Estado tem que ser tratado com dignidade. O leitor certamente argumentará, "mas o criminoso não respeitou a dignidade da vítima". É certo, mas o Estado não pode nivelar sua conduta pelo comportamento do criminoso. $\mathrm{O}$ fato de o cidadão não ter tratado a sociedade como deveria e ter sido condenado por isso não é justificativa para a sociedade tratá-lo da mesma forma. (MARTINS, 2005, P.110)

Moralmente, a interpretação social dessa conjuntura é totalmente de negação e repúdio, visto que se associa um detento a um homem extraviado de direitos.

Infelizmente esse sentimento de ódio ao acreditar que os Direitos Humanos estariam "defendendo" o presidiário dificulta o conhecimento e a compreensão das regras jurídicas que determinam quais são os direitos de condenados por crimes que devem ser suprimidos, e quais devem ser preservados. (ZAPATER, 2017, site Justificando $^{51}$

Não se põe em pauta a discussão de justo ou injusto, a pena de prisão implica em perda de liberdade, "direito à vida e à integridade física não estão incluídos nessa lista. Portanto, é ilícito matar e ferir pessoas que estejam em cumprimento de pena privativa de liberdade" (ZAPATER,2017). Segundo Carvalho Filho (2002):

"Nas prisões brasileiras a realidade é realmente bem diferente do normatizado. Os cativos sofrem constantes agressões, tanto físicas quanto morais, por parte dos companheiros de cela e dos agentes do Estado, estes últimos impondo uma espécie de regulamento carcerário, que não está consignado na legislação, e funciona como uma sanção retributiva ao mau comportamento do preso." (CARVALHO FILHO, 2002, p.23)

O coordenador nacional da Pastoral Carcerária, Padre Valdir João Silveira, em entrevista à revista Carta Capital, enfatizou a violação aos direitos dos presos nesse aspecto:

“É a instituição [prisão] na qual se garantem as violações de diretos básicos da pessoa. Então, tudo o que vai a favor do direito de alguém é quebrado. A regra está ali para quebrar os direitos básicos da pessoa. A pessoa é presa para lhe ser retirada a liberdade de ir e vir. Todos os demais direitos são garantidos pela lei,

\footnotetext{
${ }^{51}$ Retirado do artigo Porque o Estado deve indenizar familiares de detentos mortos? Autora Maíra Zapater.
} 
porém todos acabam violados por essa instituição.” (REVISTA CARTA CAPITAL, 2017)

Visto que o Estado como órgão administrativo deve garantir todos os direitos listados e quando houver mitigação dos mesmos, ele deve assumir a responsabilidade pelos danos causados.

\subsection{RESPONSABILIDADE DO ESTADO POR DANOS ACOMETIDOS AOS INDIVÍDUOS DO SISTEMA PENINTENCIÁRIO.}

O Estado é o órgão que organiza, regula e preserva o Sistema Carcerário, ele coordena as ações dos detentos e aplica sanções em determinados crimes. A realidade dos cárceres é infortuna, circunstância deplorável onde os presos são perceptíveis a superlotação, ausência de estruturas e espaço para alojamento, extrema insalubridade, incidência de enfermidades infecto-contagiosas e em última instância mortes violentas e agressões, realizadas por outros detentos ou por agentes carcerários. É emergente a necessidade de melhorias para reduzir os danos causados a estes seres humanos, viventes de uma realidade tão humilhante e lastimosa. Estas condições ferem gravemente o direito Constitucional, que assegura a dignidade e a integridade física e moral, princípios que não deveriam ser mitigados a nenhum homem.

A responsabilidade do órgão administrativo por motivo de danos causados aos presidiários é decorrente das garantias asseguradas aos indivíduos sob sua tutela. No entanto, quando não se protege estes homens, é passível a abertura de um processo indenizatório contra o Estado. Como forma de exemplificar, seria a mesma prerrogativa de pagamento a família de policiais mortos em combate, e não se coloca em questão a moral dos homens (detento e policial) e sim, que ambos estavam sob a responsabilidade do Estado que devia a ambos, condições íntegras.

A grande dificuldade está na impunidade do órgão em se responsabilizar pelos danos causados, usando da ação ou omissão de seus agentes. Não serão abertos processos indenizatórios instantaneamente, um familiar ou a própria vitima devem acionar a Fazenda Pública, a fim de receber o montante. O recebimento configura-se quando se comprova o nexo causal.

Nexo Causal é a ligação entre o dano deturpado e a negligencia do órgão na preservação do bem perdido. Quando se comprova o nexo o processo é deferido e cabe ao juiz determinar o quantum indenizatório a vitima, por falta de acesso, aos seus familiares. 
O Direito brasileiro segue corrente que necessita somente da demonstração desse nexo causal. Dessa forma, a responsabilidade objetiva é a teoria utilizada para determinar ao Estado indenizações pelos danos causados aos indivíduos, para isto, não se invoca o dolo do agente, necessita-se da comprovação da negligência com os apenados. Quando finalizada a etapa objetiva, o Estado pode realizar uma ação regressiva, de forma subjetiva, se o funcionário obtiver parcialidade (ou totalidade) de culpa a fim de devolver ao Estado, a indenização antes paga.

Claramente não há dinheiro nos cofres públicos suficiente para pagar todos os processos abertos contra o Estado. $\mathrm{O}$ encargo da administração pública não se adquire sob qualquer prejuízo ao homem. Se outro motivo levou ao dano, sem este estar ligado à administração, haverá isenção total ou parcial do ressarcimento. Casos em que há uma força maior são impossíveis de delimitar um nexo causal. Conclui-se que o Estado não está ordenado a arcar com todo e qualquer delito, ele compromete-se a realizar um funcionamento administrativo eficaz.

\section{CONCLUSÃO}

Dano Moral é a perda de certo bem imaterial e subjetivo, não pode ser calculado em patrimônio. Entre eles estão à honra, a imagem, a privacidade, a integridade física e a dignidade do homem. A fim de restaurar o bem ou ainda o sofrimento decorrente da ausência destes valores, é passível a abertura de um processo de indenização contra o causador do dolo. O artigo 186 do Código Civil brasileiro denomina esse dolo com ato ilícito, o art. 927 complementa afirmando que dano de qualquer natureza admite medida ressarcitória.

O detento perde direitos em virtude da condenação penal, a liberdade é um deles, mas a integridade física e moral e a dignidade permanecem como direitos inerentes. No entanto, são os mais violados no Sistema Prisional que deveria fielmente aplicar condições íntegras. Como o Estado é o órgão que governa e sistematiza o Sistema Carcerário, cabe a ele assegurar o mínimo a todos àqueles que estão sob sua tutela, desde os policiais, aos agentes carcerários até os detentos.

A fim de receber o ressarcimento necessita-se de comprovar o nexo causal, isto é, a ligação entre o bem perdido e a negligencia do órgão em preservar tal bem. Quando comprovado o nexo o processo é deferido e o montante será calculado, obviamente o detento não recebera o dinheiro, quem recebera será um familiar, dependendo do grau de parentesco. 
A decisão do quantum é o debate recorrente porque se o dano moral é uma perda imaterial, seria impossível medir um montante que reparasse ou diminui-se o sofrimento. $\mathrm{O}$ regulamentado é que cabe ao julgador decidir o valor, recomenda-se que ele balanceie a profundidade do dano causado, a reincidência do ato ilícito e a condições socioeconômicas do causador do dano e da vítima, dessa forma haverá uma decisão justa para ambos os envolvidos.

O Estado infelizmente é majoritariamente omisso em relação aos danos causados aos indivíduos nos centros prisionais, cabe a um familiar recorrer a uma corte denunciando as condições em que passam os detentos. Não há dinheiro suficiente para remunerar qualquer processo aberto contra o Estado, mas comprovado o nexo causal e o dano não for devido a um caso fortuito ou de força maior, a indenização será paga.

O órgão administrativo ainda poderá abrir um processo contra o agente penitenciário, se comprovada culpa por parte do funcionário, essa ação é regressiva e devolve ao Estado o montante gasto na anterior reparação por Dano Moral.

A realidade do Sistema Carcerário brasileiro é alarmante, insalubridade, incidência de doenças, pragas (ratos e baratas), ausência de auxilio médico, superlotação, falta de alojamentos e presídios que suportem o grande numero de detentos. Essa dura veracidade denota a negligencia do órgão em assegurar os direitos fundamentais a esses indivíduos.

Conclui-se então que o ressarcimento decorre dos danos morais causados ao homem privado de liberdade, este vivente de um sistema prisional com superlotação, ausentes de estruturas e espaços físicos, insalubridade e incidência de doenças e etc. O Estado como mantenedor de condições mínimas aos que estão sob sua tutela, é responsabilizado quando tais direitos não são assegurados.

\section{REFERÊNCIAS BIBLIOGRÁFICAS}

AMARAL, Antônio Carlos Melo do. Dano Moral e a Fixação do Quantum Indenizatório na Justiça do Trabalho. Acesso em: 20/06/2017, disponível em: $<$ https://jus.com.br/artigos/44537/dano-moral-e-a-fixacao-do-quantum-indenizatorio-najustica-do-trabalho, 2015>. 
BELMONTE, Alexandre Angra. Tutela da Composição dos Danos Morais nas Relações de

Trabalho: identificação das ofensas morais e critérios objetivos para quantificação. São Paulo: Ed. LTr, 2014.

CAHALI, Yussef Said. Dano Moral, Editora Revista dos Tribunais SP, 2ª edição, 1998. CARVALHO FILHO, Luiz Francisco. A Prisão. São Paulo: Publifolha, 2002.

DIAS, José Aguiar. Da Responsabilidade Civil. V. I. Editora Forense, RJ, 10ª edição, 2006. MACHADO, Pennache Zely e MORISHITA, Renata. "A Quantificação do Dano Moral”. Acesso em: 19/06/2017, Disponível em <http://www.unitoledo.br, 2005>.

MAGAlHãeS, Teresa Ancona Lopez de. O Dano Estético. São Paulo: Ed. Revista dos Tribunais, 1980 .

MARTINS, Ives Granda da Silva. Conheça a Constituição: comentários a Constituição Brasileira. Barueri, SP: Manole, 2005. V.1, p.110.

MEIRELlES, Hely Lopes. Direito Administrativo Brasileiro. 31. Ed. São Paulo. Malheiros, 2005. p. 667.

MOLINA, Antônio Garcia-Pablos de; GOMES, Luis Flavio; Criminologia: introdução a seus fundamentos teóricos: introdução as bases criminológicas da lei 9.099/95, Lei dos Juizados Especiais Criminais. 6. Ed. São Paulo: Revista dos Tribunais, 2008. P. 156-157.

RANGEL, Anna Judith. Violações aos Direitos Humanos dos Encarcerados no Brasil: perspectiva humanitária e tratados internacionais. Acesso em: 19/05/2017, Disponível em: $<$ https://ninhajud.jusbrasil.com.br/artigos/123151293/violacoes-aos-direitos-humanos-dosencarcerados-no-brasil-perspectiva-humanitaria-e-tratados-internacionais, 2014>.

SANTOS, Pablo de Paula Saul, Dano Moral: um estudo sobre seus elementos, Âmbito Jurídico, Acesso em: 20/05/2017 disponível em: <http://www.ambitojuridico.com.br/site/?n_link=revista_artigos_leitura\&artigo_id=11819, 2017>. 
ZAPATER, Maíra. Por que o Estado Deve Indenizar Familiares de Presos Mortos? Acessado em: 12/05/2017, Disponível em:

<http://justificando.cartacapital.com.br/2017/01/13/por-que-o-estado-deve-indenizarfamiliares-de-presos-mortos/, 2017>.

\title{
INDEMNITY OF PRISONER'S FAMILY
}

\begin{abstract}
Aiming comprehend the criminal code in face of the inmates, this article objectify elucidate the reasons of the repayment. It is proposed to understand the reasons for indemnity since the fundamental rights recognize in the Federal Constitution are for everyone. The methodology used was dialectic and dialogic; the first showed the perspective of several authors, checking these perspectives, appears similarities and differences, defining a conclusion. The second method dialogs with others knowledge areas as history and sociology. The approach initiates illustrating the bad reality of system prison and the lack of a specify code. As result was confirm that indemnity are paid because the government is irresponsible towards the damage caused to inmates. Besides, the civil population manifests repudiation to situations satisfactory to prisoners, therefore the imprisoned is wrongly excluded of the society.
\end{abstract}

Keywords: Prisoner. Indemnity. Prison System. Nexus of the cause. Government. 